\title{
In Memoriam: A Personal Reflection of Petal Kinder
}

\author{
RoBIN GARDINER ${ }^{1}$
}

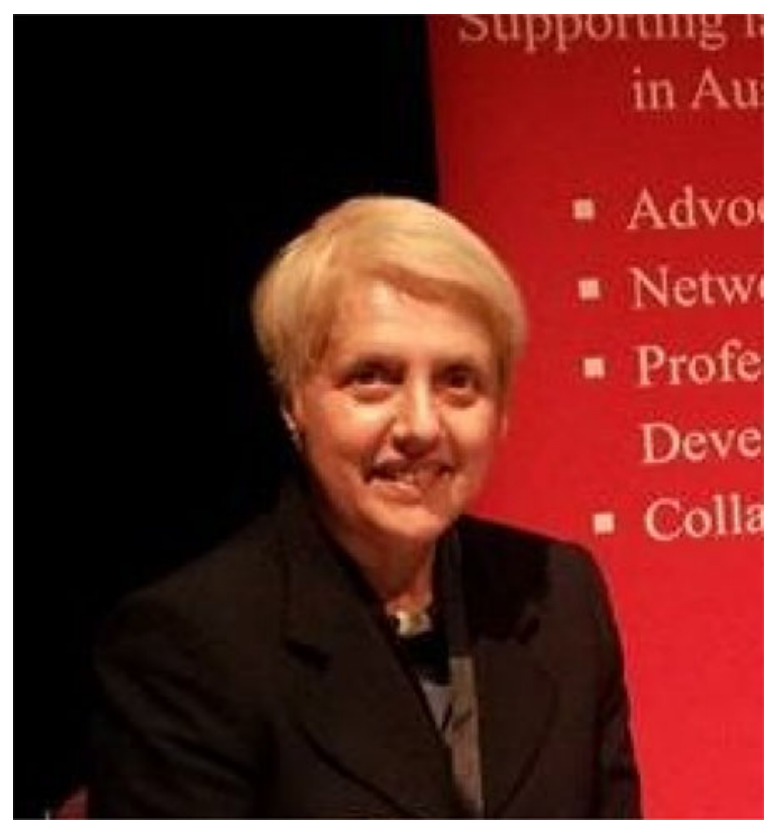

Petal Kinder died on April 21, 2019. Her passing was a blow to the law library world, and it is my privilege to write a few words about her. When the Editor of this journal, Mark Engsberg, asked me to write about Petal, I felt, and still feel, a bit of a fraud. I knew Petal for less time than many other law librarians knew her, never became the close friend that others did, and I never worked with her-so I feel that others are far more qualified to reflect on Petal's life in law librarianship. Mark assured me that Petal would be thrilled, as she had always thought highly of me. I was humbled and delighted by that, and of course agreed!

My reflection is purely personal, and therefore rather indulgent - I hope the readers will forgive this and bear with me. I note that I am the Co-editor of the Australian Law Librarian, and we published a feature on Petal in vol 27(2) 2019..$^{2}$ This little piece uses some of what I wrote in the Editorial for that issue, so, as we say on the e-lists - apologies for cross-posting.

The title of this piece - 'The Kinder Surprise' 3 — in many ways sums Petal up for me; small and surprising. Petal really was diminutive, and I (especially in heels) am tall. When I would chat to her at social functions, I'd have to bend almost double to hear her over the din and would always leave such events with a wretchedly sore back. We took to meeting alone in quiet cafes - a much more satisfactory arrangement. I hasten to add that Petal was small in

${ }^{1}$ C Robin Gardiner 2020. The author is Law Research Service Manager - Melbourne Law School at University of Melbourne, Melbourne, Australia.

${ }^{2}$ In a shameless act of promoting our journal, I note that it is available on HEIN Online.

${ }^{3}$ I presumed that everyone knows what a Kinder Surprise is, but I learned recently that they were banned for many years in the United States .... so, if you don't know, they're little chocolate eggs with a toy (the surprise) inside. 
stature only; her personality and charisma filled any room she was in. And her surprising-ness: Petal never ceased to amaze me with her inexhaustible drive and her passion for the profession and the professional associations with which she was involved. This involvement was never on the sidelines - she held every office-bearing position on the ALLA Board, including President, and was President of the International Association of Law Libraries (IALL) from 2010-2013 - a very prestigious role. If you look up "indefatigable" in the dictionary, you'll see a photo of Petal.

I first met Petal in 2008, when I had just rejoined the Australian Law Librarians' Association (ALLA) after several years out of the profession. Petal was ALLA President. Within about five minutes of joining, I found myself the ALLA Website Coordinator, a very busy volunteer role I did for five years. In 2016, when Petal was on the IALL Board, I found myself on the Local Planning Committee for the 2019 IALL Conference in Sydney - another big job ("big" is an HUGE understatement, but I'm trying to restrict my use of hyperbole). I say "found myself" as if I have no idea how these things happened and as if I had no choice. The simple truth is that I never learned how to say no to Petal - a sentiment many others have echoed! As I worked through my weekends in both these roles, I often cursed my inability to say no. However, not knowing how to say no to Petal meant that I have become involved in professional associations and far more involved in my profession than I would have otherwise. I have had opportunities I'd never otherwise have, and met law librarians from all over the world, whom I would otherwise never have met. My involvement has greatly enriched my professional experience and I'm so happy to give back to such a nurturing profession, and so grateful to Petal for getting me involved. She was a true mentor-generous with her time and advice - and a role-model for us all-involved in every aspect of her professional associations and employed at the peak of the law library profession, as the Librarian of the High Court of Australia.

While I never worked with Petal, over the years I spent a lot of time with her - on Committees, at conferences and social events. As we planned the 2019 IALL conference, we met regularly to discuss plans, progress, and strategies. Our meetings were always fun as well as productive, and we invariably digressed wildly — Petal was a great source of fascinating and hilarious "inside" information about the goings on at a high level in her various spheres of work and committees - and I loved hearing about it! We met for dinner in London after the 2016 IALL Conference in Oxford, after which the IALL Board had held what was apparently a particularly "robust" meeting-Petal's account was full of passion and outrage and so funny (and my lips are forever sealed). She could be utterly charming and utterly scathing. She was also disarmingly self-deprecating, telling stories about her own misadventures and foot-in-mouth moments that made me laugh till I nearly cried. It was always a delight to spend time with her.

Petal was a strong advocate for the education of librarians, for the education of and service to our users, for technological advances, for sharing and networking. She was always, always, always planning, strategizing, networking, negotiating, and thinking about how things could be improved - whether it was making ALLA a truly national, rather than state based, association, networking with ALIA (the Australian Library and Information Association) to achieve shared goals, organizing a new website for ALLA, or organizing a conference-basically, she got stuff done. I felt tired all over watching her in action - she never stopped. All this work was of course voluntary, and she was an inspiration regarding what can be achieved by voluntary organizations. Petal was also a great communicator and brilliant delegator - with a constant stream of people who admired her and who were willing to put her plans into action.

Petal was a driving force behind the 2019 IALL Conference in Sydney, championing the first IALL Conference in Australia since 1999. I'll always be sad that she didn't live to experience it because she had worked so hard to make it happen. Petal stayed on in her role of Board Liaison for the Conference as long as she could, at which point she was replaced by the supremely calm and able Kurt Carroll. We were a small Conference Local Planning Committee (LPC) who had been hand-picked by Petal, which was itself an honor, and rather humbling. When I'd get a little overwhelmed with the enormity of the task, I used to think (with gritted teeth, bleary eyes, and pounding head) that the only thing that kept me going was that I wanted to make Petal proud, and to prove that her choice of LPC members was justified - and I'm sure I speak for the others on the LPC when I say this. I really do think she would have been proud-the Conference was a great success. I'm so glad she asked me to do it, and I'm so glad I did. The Australian Law Librarian now offers an on-going annual bursary to attend the IALL Conference, which we have named the Petal Kinder Memorial Scholarship.

The last and biggest surprise Petal had in store for me was that she was mortal. Petal didn't accept that —she talked of her illness as if it was simply a glitch, and that she would soon be back in top form. As her illness progressed and she was forced to slow down and spend time in hospital or at home 'resting', she was so cross and impatient, 
complaining about what a boring waste of time it was to be unwell. During Petal's time as Editor of the Australian Law Librarian, she often started her Editorials with a bit of a poem-ranging from Shakespeare to Banjo Patterson. I feel it fitting to end with, not quite a poem, but an especially fitting quote from Somerset Maugham, which echoes Petal's intolerance - and I think she would approve: "Dying is a very dull, dreary affair. And my advice to you is to have nothing whatever to do with it."4

Petal enriched the lives of so many, will be missed by all who knew her, and will live on in our memories and hearts. So maybe she's immortal after all! The law library world is a poorer and smaller place without her. It was my absolute privilege to know her.

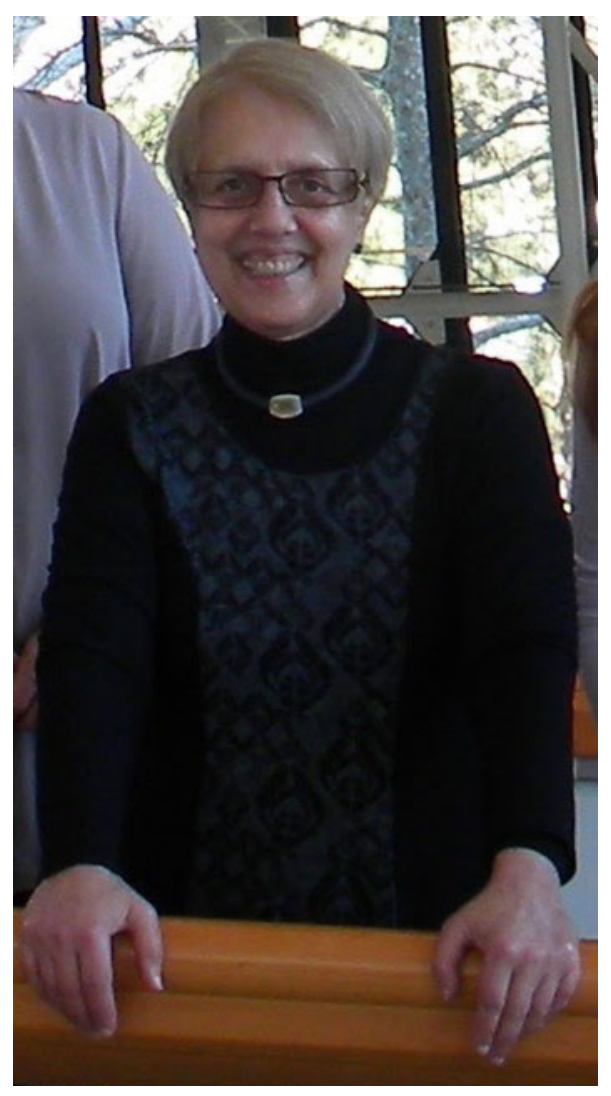

\footnotetext{
${ }^{4}$ Quoted in Robin Maugham, Conversations with Willie: Recollections of W Somerset Maugham (WH Allen, 1978).
} 